$\begin{array}{ll} & \text { Etnográfica } \\ \text { etnográfica } & \text { Revista do Centro em Rede de Investigação em }\end{array}$

Antropologia

vol. $14(1) \mid 2010$

Vol. $14(1)$

\title{
Marcio Goldman, Como funciona a democracia: uma teoria etnográfica da política
}

\section{Susana Durão}

\section{OpenEdition}

\section{Journals}

\section{Edição electrónica}

URL: https://journals.openedition.org/etnografica/371

DOI: 10.4000/etnografica.371

ISSN: 2182-2891

\section{Editora}

Centro em Rede de Investigação em Antropologia

\section{Edição impressa}

Data de publição: 1 fevereiro 2010

Paginação: 201-204

ISSN: 0873-6561

\section{Refêrencia eletrónica}

Susana Durão, «Marcio Goldman, Como funciona a democracia: uma teoria etnográfica da política»,

Etnográfica [Online], vol. 14 (1) | 2010, posto online no dia 20 julho 2012, consultado o 12 fevereiro

2022. URL: http://journals.openedition.org/etnografica/371 ; DOI: https://doi.org/10.4000/etnografica. 371

Este documento foi criado de forma automática no dia 12 fevereiro 2022

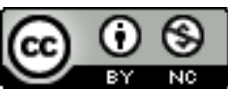

Etnográfica is licensed under a Creative Commons Attribution-NonCommercial 4.0 International License. 


\title{
Marcio Goldman, Como funciona a democracia: uma teoria etnográfica da política
}

\author{
Susana Durão
}

\section{REFERÊNCIA}

Mario Goldman, Como funciona a democracia: uma teoria etnográfica da política, Rio de Janeiro, Editora 7Letras, 367 páginas.

1 A síntese deste livro é aparentemente simples e poucos antropólogos ousariam criticála: "a democracia, como qualquer sistema político ou social, é composta por normas, mas também depende dos comportamentos efectivamente levados a cabo para funcionar" (p. 200). Goldman propõe o estudo das intimidades da vida quotidiana de quem faz política. No mesmo sentido em que se levam a sério as músicas e religiões na antropologia, o autor propõe que se leve a sério o que os membros de blocos, terreiros de candomblé ou outras formas de associação têm a dizer sobre os políticos e sobre a política. Goldman procura respeitar a sensibilidade da filosofia política dos militantes afro-culturais de ilhéus, na Baía (Brasil).

2 Um aviso: é preciso ter calma para ler este livro. O texto está cheio de dados etnográficos, de movimento, de devir ("devir--nativo"), e pára em alguns momentos para nos oferecer flashes teóricos e insights reflexivos bastante seguros. O tempo é um aspecto curioso do livro. Ele demorou tempo a ser produzido, entre o primeiro trabalho de campo em 1982 e a edição em 2006, com vários incidentes pelo caminho e, claro, com várias aproximações e afastamentos do campo ao longo dos anos. Goldman decidiu fazer uma etnografia com dados que dizem respeito ao envolvimento político do movimento afro-cultural de Ilhéus ao longo de um período de vinte anos não consecutivos. Mas, simultaneamente, desenha uma etnografia em movimento. 0 ritmo da descrição é descontínuo, como os materiais, acelera para logo depois desacelerar, e 
não corre linear, anda para a frente e pode seguir em flashback. Por um lado, dir-se-ia que a inspiração deleuziana e guattariana se imprime desde logo no estilo da escrita, mas que o conselho de B. Latour de uma certa lentidão e modéstia da etnografia foi seguido. A obra é original e furta-se a classificações genéricas ou simples, quer no quadro da antropologia quer no quadro das ciências sociais. Mas, por isso mesmo, o texto é estimulante.

O posicionamento epistemológico começa logo por ser invulgar, sobretudo para quem não conhece o contexto de intensa produção intelectual brasileira. Trata-se de restituir à etnografia a sua centralidade no projecto de conhecimento antropológico. É uma antropologia da política e uma teoria etnográfica da democracia, fiel ao ponto de vista nativo e à tradução de sentidos etnográficos em teoria etnográfica, não impondo aos dados um modelo abstracto pré-concebido. A teoria antropológica é aqui afirmada no sentido de ajudar a criar uma matriz de inteligibilidade maior a partir de dados e contextos concretos. Procura superar binómios de posicionamento intelectual antigos, tais como genérico/particular, práticas/normas, realidade/ideal. Evita colocar questões abstractas a partir de estruturas, funções e processos, dirigindo-se toda a etnografia para os funcionamentos e práticas - neste caso, da democracia. Assim, a ambição é situar a etnografia como modo de entendimento do sistema político. A etnografia deixa de estar reduzida ao estatuto de tarefa ilustrativa ao serviço de uma antropologia (pretensamente mais abstracta) e ganha em dinâmica epistemológica.

4 A política é então perspectivada não em si mesma e por si mesma, mas descodificada nos filtros oriundos de outros campos sociais, inspiração que o autor busca em M. Foucault. Goldman perspectiva a política sem ciência ou "ao lado" da ciência política e dos seus mais directos reformadores; a política em prática, não a política em falta; a política sem centros e periferias, devolvida à vida quotidiana. Trata-se de conhecer a democracia "representativa" e participada por uma série de "actores secundários".

5 O livro divide-se em seis capítulos que apontam o tempo dos eventos mais centrais da política em Ilhéus e, simultaneamente, o tempo da etnografia dos eventos. Não tem conclusão, porque a história contada e as tensões prometem manter-se.

6 Deixem-me pontilhar esta recensão de alguns dos insights de teoria etnográfica que podem servir-nos a todos para pensar. É oferecida uma discussão sobre o carácter invasivo da política em Ilhéus, o seu penetrar constante de domínios dos quais deveria estar excluída, como o parentesco, a arte ou a religião, e a concomitante possibilidade de ser praticada não apenas por aqueles que estão na sua esfera oficial e partidária. A política é polissemântica, transitória, mas também pode ser poluente e disruptiva (pp. 119-121). A política é claramente uma oportunidade (pp. 128-129).

7 A teoria da segmentaridade sai da gaveta e é revista, já não apenas em função da explicação de morfologias sociais de sociedades sem Estado, o que explicaria o seu "tipo" exótico, mas como "aspecto" universal da vida política. Libertando o conceito do seu viés sociologizante, Goldman propõe que a segmentação seja entendida como questão etnográfica e no sentido processual do termo, em que vão sendo criadas, por diversos movimentos, em diversas orientações e modalidades, estruturas propriamente segmentares. Estas podem formar-se de modo arborescente (piramidal) ou rizomático (categorias que o autor recupera de G. Deleuze e F. Guattari). As modalidades de segmentação apontadas pelos mesmos autores - binárias, circulares, lineares - são discutidas em contexto. Goldman aponta e estuda a tendência federalizante nos blocos (já antes enunciada por M. Agier), no sentido em que, além de se articularem com 
múltiplas formas de organização, podem agregar-se para negociar com a prefeitura, por exemplo.

8 O Estado está permeado pela segmentação, não lhe é oposto. Se a democracia parece estar voltada para a administração de conflitos, ela não funciona linearmente por meio de acordos e pactos. Goldman crê que se trata de um processo de distribuição de conflitos, lançando conflitos contra conflitos, de modo a controlar e impedir a eclosão de outros, supostamente mais graves, que ameaçariam a estabilidade e a permanência do sistema. Goldman segue então M. Herzfeld na ideia de que a segmentaridade não reside na divisão de uma suposta unidade, mas na conversão de multiplicidades em segmentos, em unidades simultaneamente divisíveis e unificáveis, de acordo com múltiplas estratégias que vão da repressão à resistência, passando pela manipulação e pela cooptação (pp. 141-182).

Através da história do Centro Afro-Cultural de Ilhéus, Goldman propõe interpretar três modalidades de relações sociopolíticas constantemente abordadas pelas ciências sociais brasileiras: a compra de votos, as promessas eleitorais e, de modo mais amplo, a "fraqueza" das instituições democráticas - como meios de viver e pensar a política (pp.166-173). Goldman discute a conexão entre aspectos geralmente tidos como fenómenos separados: a inflexão constante da representação política moderna e da participação eleitoral, a forma como as pessoas se envolvem na captação de votos no sistema eleitoral brasileiro, as pesquisas e os debates eleitorais, a distribuição de cestas básicas, os momentos de festa e de controvérsia (cap. 4).

Em Goldman, o Estado não é apenas instituição, mas modo de funcionamento, forma de poder, de "captura" e de produção de unidades, conceitos que mais uma vez pede emprestados a Deleuze e Guattari. É neste eixo reflexivo que surge discutida uma das mais complexas temáticas do presente, a questão do racismo, como prática e forma de poder, como forma de inclusão diferenciada. Mas são também discutidas as relaçães entre o movimento afro-cultural em Ilhéus e o Estado, a relação dos blocos com a política partidária; as ambiguidades em uso no termo "cultura", que tanto serve para falar de formas de sociabilidade como para fazer parte de um arsenal de aparelhos de captura de que dispõem os Estados e os poderosos; as burocracias estatais e os diferentes enredos da política nativa como territórios de bruxaria, onde umas pessoas são eliminadas por outras na luta pelos poucos espaços disponíveis.

11 Goldman vai dialogando com um conjunto de autores com quem partilha afinidades teóricas, não apenas temáticas. 0 livro revela a sua própria trajectória por dentro da teoria antropológica. Esperemos que a história da etnografia política de Goldman não termine aqui e nos surpreenda de novo.

\section{AUTORES}

\section{SUSANA DURÃO}

ICS - Universidade de Lisboa 